Paliç Şadoğlu, G. \& Sağlam Arslan, A. (2018). Cross grade analysis of prospective science teachers' perceptions related to the concept of atom. Abant İzet Baysal Üniversitesi Eğitim Fakültesi Dergisi, 18 (3), 1678-1701.

Geliș Tarihi: 02/03/2018

Kabul Tarihi: 18/09/2018

\title{
CROSS GRADE ANALYSIS OF PROSPECTIVE SCIENCE TEACHERS' PERCEPTIONS RELATED TO THE CONCEPT OF ATOM
}

\author{
Günay PALİÇ ŞADOĞLU* \\ Ayşegül SAĞLAM ARSLAN**
}

\begin{abstract}
The purpose of this study is to reveal the changes in the perceptions of prospective science teachers on the concept of atom in terms of their levels of education. In the scope of the study, a two-part word association test was developed as the data collection tool, and it was applied on a total of 194 prospective teachers who were studying in the degree program for science teaching. The data obtained from the first part of the test were analyzed and the concepts that the prospective teachers associated with the concept of atom were determined, and the way these varied based on class levels was analyzed. Using the data obtained by the second part of the test, the meanings of the sentences the participants formed in relation to the atom and related concepts and the way this nature changed based on class levels were analyzed. The finding that prospective teachers on different levels associated similar concepts with the atom and formed sentences that contained alternative concepts in a similar way, showed that the atom, which is a subject of teaching on different levels since the secondary schools, was not internalized in agreement with scientific knowledge by a significant proportion of the prospective science teachers. Additionally, the analyses showed that no significant change occurred in learning the atom and related concepts based on levels of education.
\end{abstract}

Key Words: Concept of atom, prospective science teacher, word association test

\section{FEN BİLGİSI ÖĞRETMEN ADAYLARININ ATOM KAVRAMINA İLIŞKİN ALGILARININ SEVIYYLER ARASI KARȘILAȘTIRMALI ANALIZI}

\section{ÖZET}

$\mathrm{Bu}$ araştırmanın amacı fen bilgisi öğretmen adaylarının atom kavramına ilişkin algılarının, öğrenim düzeylerine göre değişimlerini ortaya koymaktır. Araştırmada veri toplama aracı olarak iki bölümden oluşan bir kelime ilişkilendirme testi geliştirilerek toplam 194 fen bilgisi öğretmen adayına uygulanmışırı. Testin ilk bölümünden elde edilen verilerin analizi yapılarak öğretmen adaylarının atom kavramını ilişkilendirdikleri kavramlar belirlenmiş ve bunların sınıf seviyesine göre nasıl farklılaştığ 1 analiz edilmiştir. Testin ikinci bölümünden elde edilen veriler yardımıyla öğretmen adaylarının atom ve ilișkili kavramlarla ilgili kurdukları cümlelerin içerdiği anlamlar ile sınıf seviyelerine göre değişimi analiz edilmiştir. Farklı seviyelerdeki öğretmen adaylarının benzer kavramları atomla ilişkilendirmeleri ve benzer nitelikte alternatif kavramlar içeren cümleler kurmaları, ortaokul yıllarından itibaren farklı seviyelerde öğretim konusu olan atomun öğretmen adaylarının önemli bir bölümü tarafından bilimsel bilgilerle uyumlu şekilde içselleştirilmediğini göstermektedir. Ayrıca yapılan analizler, öğrenim seviyesine göre atom ve ilişkili kavramların öğreniminde not edilir nitelikte bir farklılaşmanın olmadığını göstermektedir.

Anahtar Kelimeler: Atom kavramı, fen bilgisi öğretmen adayı, kelime ilişkilendirme test

*Dr., RTEU, Faculty of Education, gunaypalic@hotmail.com

**Prof. Dr., KTU, Faculty of Education, asaglam_arslan@yahoo.fr 


\section{INTRODUCTION}

As known, the concept of atom that students face in different levels from middle-school to university is one of the fundamental concepts of science. Considering the role of the atom, which is fundamental in explaining the structure of matter, in different disciplines and even in real life, the importance of education activities carried out in relation to this concept is clear.

Due to its abstract and hard structure to be explained, the atom and related concepts have been subjects of several studies. Considering their point of focus, these studies may be classified into two groups: assessment studies and educational activity improvement/development studies. There are numerous studies on assessments regarding issues such as cognitive models, misconception, alternate concepts, learning disability and learning levels on national and international levels (Ben-Zvi, Eylon \& Silberstein, 1986; Demirci, Yılmaz \& Şahin, 2016; Doymuş, Koç, Akkuş, Başaran \& Zorlu, 2012; Griffiths \& Preston, 1992; Justi \& Gilbert, 2000; Karagöz \& SağlamArslan, 2012; Nakiboğlu, Karakoç \& Benlikaya, 2002; Park \& Light, 2009; TaylanY1ld1z, 2006). Similarly, it is also known that the literature covers a vast amount of studies that focus on eliminating misconceptions, alternate concepts, learning disability and learning levels in teaching the concept of atom (Ak1ll1, 2011; Baybars \& Küçüközer, 2014; Çalıklar, 2015; Çökelez \& Dumon, 2005; Demircioğlu, AltuntaşAydın \& Demirci, 2012; Kahraman \& Demir, 2011; Pringle, 2004; Tsaparlis \& Papathotis, 2009). Comprehensive analysis of the concepts summarized above shows that students find the concept of atom difficult to understand and explain due to its microscopic and abstract structure, thus, they misunderstand the atom and relevant concepts and find them difficult to understand, and they have various alternate conceptions and misconceptions.

Considering the chronological development of atom models, significant developments have taken placed since the 1800 s up to our time. Studies that started with the model proposed by Dalton in 1805 advanced until the modern atom theory, and they were improved by the contributions of Schrödinger and Heisenberg. In the Dalton (1805) atom model, it is stated that elements consist of atoms, all atoms of an element are identical, atoms form the larger pieces called molecules by gathering together, atoms are indivisible, and they have the shape of a solid sphere (Justi \& Gilbert, 2000). Thomson (1897) stated that atoms have small, negatively-charged particles that are called electrons, and positive and negative charges are distributed in the sphere to achieve the balance of electrical charge (Justi \& Gilbert, 2000). Rutherford (1911) indicated that the mass and the positive charge in an atom are concentrated in the center of the atom called a nucleus. The nucleus is 10000 times smaller than the atom and electrons more in circular orbits around the nucleus via the centripetal force of the nucleus (Justi \& Gilbert, 2000). In the Rutherford atom model, as the structure of electrons was explained by classical mechanics, the issue of why electrons do not fall onto the nucleus could not be explained (Justi \& Gilbert, 2000). Bohr (1913), in his atom model where the behaviors of the hydrogen atom and some single-electron ions were explained, stated that electrons might not be on a random circular orbit around the nucleus but may be located on circular orbits that have a certain energy (energy levels) and electrons have the energy of the energy level they are located on, but he could not explain the behaviors of atoms with multiple electrons (Akyol, 2009; Özgür \& Bostan, 
2007). According to modern atom theory, as electrons may be located in more than one place at a time, their position cannot be known precisely and the regions where electrons have high probability of placement are called orbitals (Justi \& Gilbert, 2000).

Concepts used by individuals to make sense of events and relationships among events have a significant place in physics education (Ayvacı \& Devecioğlu, 2009). The role and importance of the concept of teaching/learning in teaching relevant subjects led to significant research conducted in the field by staying under the radar of researchers especially in the field of science education for a certain and long time. Considering that learning concepts is highly important to learn about a subject, it is argued that students form conceptual constructs in their cognitive structures that are thought to be meaningful but actually do not have much to do with scientific knowledge (Kurt \& Ekici, 2013b). It is reported that these misconceptions in these conceptual constructs obstruct accurate learning and lead to new misconceptions (Clement, 1982; Yağbasan \& Gülçiçek, 2003). As known, according to the common claim supported by all current theories of education, the preliminary knowledge (that includes misconceptions, alternate concepts, etc.) of students when they arrive at the learning environment has the quality to potentially obstruct learning. As learning is the product of an interaction between the existing concepts in the mind of the individual and newly acquired concepts, it is necessary to reveal the general characteristics of the concepts in students' minds.

The misconceptions and lack of knowledge of prospective science teachers about the concept of atom, will make it harder for them to understand some subjects about their field and carry out their profession in the future, and they may lead to misunderstandings, which affects the success of their students in science classes and reduces their interest in these classes (Kaya, 2010). Moreover, it is also stated that any erroneous information held by prospective teachers may affect their students' learning in the future, in other words, the misunderstandings held by prospective teachers may lead to emergence of misconceptions in their students via in-class interactions during education practices (Bradley \& Mosimege, 1998). It is also known that the knowledge base of teachers regarding their own field either increases or restricts their students' levels of learning (Mitchner, 1994; McDiarmid \& Anderson, 1989; cited by Tezcan \& Çelik, 2009). It is reported that concepts or information that are superficially covered without learning in the correct way not only affect individuals' later periods of education, but also have the potential to cause much more significant problems in understanding and comprehension in their personal and professional lives (Schulte, 2001). In this sense, it is accepted that the process analysis of education that is carried out by considering that correct learning is a reflection of quality teaching activities is an important subject to be researched. Also, it is expected that prospective science teachers should have more qualified knowledge about basic science concepts in upper class. Because, in upper classes, basic science concepts are considered in detail in the course of material development, special teaching methods and teaching practices.

\subsection{Purpose of Study}

Accordingly, the purpose of this study is to determine the perceptions of science prospective teachers towards the concept of atom, which will allow correct and easy perception of higher-level science subject and therefore facilitation of meaningful 
learning, and to understand the effects of undergraduate programs on these perceptions. Regarding this purpose, answers were sought for the following questions;

- Which subjects and/or concepts do prospective science teachers relate the concept of atom to and how do these related subjects and/or concepts change based on the class level?

- How do prospective science teachers explain the subjects and/or concepts related to the concept of atom and how do the scientific qualities of these explanations change based on the class level?

\section{METHOD}

In the scope of this case study, what happened in a real setting was analyzed by systematically collecting data, and the results were presented. Case study is a research design that studies a case in the real-life framework of its own, and investigates cases in a versatile, systematic and in-depth way (Yıldırım \& Şimşek 2011). The resulting product is the understanding of why the case is that way and what should be focused on in more detailed for future studies (Gökçek, 2009).

\subsection{Sample}

The sample of the study consisted of a total of 194 students of science education, including 66 first year, 47 second year, 38 third year and 43 fourth year prospective teachers.

In the framework of the basic principles of the Anthropological Theory of the Didactic (Sağlam-Arslan, 2016) established by considering the fact that learning about a concept is related to the states of learning that concept and they are even reflections of the teachings that are encountered, this study analyzed the potential knowledge of the participants regarding the concept of atom. According to this, the courses in which participants encounter the concept of atom that is scheduled institutionally in formal education institutions are summarized in Table 1.

\section{Table 1.}

Courses in which participants encounter the concept of atom

\begin{tabular}{lll}
\hline \multicolumn{1}{c}{ Program } & \multicolumn{1}{c}{ Grade } & \multicolumn{1}{c}{ Units } \\
Science and & 6th grade & Grain Structure of Matter \\
Technology & 7th grade & Structure and Properties of Matter \\
Curriculum 2004 & 8thgrade & Structure and Properties of Matter \\
\hline & 9thgrade & Matter and Properties of Matter \\
High School Physics & 10thgrade & Modern Physics \\
Curriculum 2009, & 11th grade & Modern Physics \\
2011 & 12th grade & Modern Physics \\
& & From Atoms to Quark \\
\hline
\end{tabular}


Cross grade analysis of prospective science teachers' perceptions related to the concept of atom

\begin{tabular}{|c|c|c|}
\hline \multicolumn{3}{|l|}{ Table 1. continued } \\
\hline Program & Grade & Units \\
\hline \multirow{12}{*}{$\begin{array}{l}\text { High School } \\
\text { Chemistry } \\
\text { Curriculum 2007, } \\
2008,2011\end{array}$} & 9thgrade & Development of Chemistry \\
\hline & & Compounds \\
\hline & \multirow{4}{*}{ 10thgrade } & Chemical Changes \\
\hline & & Atomic Structure \\
\hline & & Periodic System \\
\hline & & Interactions between Chemical Species \\
\hline & \multirow{3}{*}{ 11thgrade } & States of Matter \\
\hline & & Electrochemistry \\
\hline & & Nuclear Chemistry \\
\hline & \multirow[t]{3}{*}{ 12thgrade } & Chemistry of the Elements \\
\hline & & Introduction to Organic Chemistry \\
\hline & & Organic Reactions \\
\hline \multirow{9}{*}{ Undergraduate } & 1st grade & General Chemistry I \\
\hline & 2nd grade & General Physics III, General Biology I (cell), \\
\hline & & General Chemistry III (Analytical Chemistry), \\
\hline & & General Chemistry IV (Organic Chemistry), \\
\hline & & Introduction to Modern Physics \\
\hline & 3rd grade & Science Teaching Laboratory Application I, \\
\hline & & Special Topics in Physics, Special Topics in \\
\hline & & Chemistry, History and Nature of Science, \\
\hline & 4th grade & $\begin{array}{l}\text { Science Teaching Laboratory Application II, } \\
\text { Chemistry and Life }\end{array}$ \\
\hline
\end{tabular}

Table 1 show that participants encounter the concept of atom in all grades from the 6th grade to the last year of their undergraduate degrees. Additionally, the table shows that the concept of atom is a subject of both Physics and Chemistry classes in all grades at the high-school level, while at the undergraduate level, this concept is included in the curriculum of 1 class in each of the 1 st and 4 th years, and in the curriculum of 5 different classes in the 2 nd and 3 rd years.

\subsection{Data Collection Tool}

A word association test was used as the data collection tool in this study. Word associations tests are a technique used in determination of psychological and sociological beliefs and attitudes in addition to analyses of conceptual constructs (Hovardas \& Korfiatis, 2006).Word association testing is an alternate measurement and analysis technique that allows revelation of the cognitive structure by making it possible to analyze the network of information in individuals' minds, the structure of the connections among the concepts that create this network, and whether these connections are significant or not, in the framework of key concept(s) (Bahar, Johnstone \& Sutcliffe, 1999; Bahar \& Özatl1, 2003; Ercan, Taşdere \& Ercan, 2010; Kaya \& Taşdere, 2016). It is seen in the literature that word association tests are used frequently for achieving different goals including revealing cognitive structures (Atabek-Yiğit, 2016; Ekici \& Kurt, 2014; Ekici, Gökmen \& Kurt, 2014; Ercan, Taşdere \& Ercan, 2010; Kaya \& Taşdere, 2016; Kurt \& Ekici, 2013a; Kurt ve Ekici, 2013b; Özata-Yücel \& Özkan, 2015), detecting misconceptions or alternate concepts (Ayaz, Karakaş \& Sarıkaya, 2016; Özata-Yücel \& Özkan, 2015), determining conceptual 
changes (Ercan, Taşdere \& Ercan, 2010; Güneş ve Gözüm, 2013; Kaya \& Taşdere, 2016; Nakiboğlu, 2008) and determining perceptions (Özata-Yücel \& Özkan, 2014; Özata-Yücel \& Özkan, 2016).

As the participants need to write down the concepts that are reminded by the stimulant word in a certain time limit in the first stage of word association testing (Gussarsky \& Gorodetsky, 1990). In this study, the prospective teachers were asked to write down the first ten words that came to their minds about the concept of atom in 30 seconds in the first stage. In the second stage, they were asked to provide more than one sentence about each concept they provided regarding the concept of atom.

Also, another reason for using the word association test in this study is that it provides more data collection in a shorter time.

\subsection{Data Analysis}

The words and concepts associated with the concept of atom by the prospective science teachers in the first stage of the word association test were categorized based on their common characteristics and a frequency table was formed. The sentences formed by the participants for the words or concepts that associated with the concept of atom in the second part of the word association test were categorized based on the meanings that contained using the categories developed by Özata-Yücel and Özkan (2015).

- Scientific information; if the sentences formed by the participants were scientifically accurate, they were classified here, and university textbooks are considered,

- Emotional information; this category included sentences that reflect the emotions and thoughts of the participants, made sense of via their part experiences and traditions that have no scientific meaning,

- Superficial information or information that contained examples from daily life; sentences used in daily life or language that have no scientific meaning were classified here,

- Unscientific information or information with misconceptions; this category included responses in which the participants tried to load scientific meanings to the key concept, but related it to the concepts and statements that have a different or erroneous meaning.

In the data analysis stage, as a part of testing reliability, one researcher determined the categories for the words and concepts that the participants associated with the concept of atom, while the other researcher controlled the data analysis. In the stage where the words or concepts that the participants associated with the concept of atom were analyzed based on the meanings they contained, both researchers examined the papers separately and made classifications. After this, the classifications with agreement were accepted, and those that were not in agreement were reevaluated and categorized.

\section{RESULTS}

Table 2 shows the distribution of words/concepts associated with the concept of atom by the prospective science teachers based on categories. 
Cross grade analysis of prospective science teachers' perceptions related to the concept of atom

\section{Table 2.}

Distribution of concepts associated with the concept of atom

\begin{tabular}{|c|c|c|c|c|c|c|c|c|c|c|}
\hline \multirow[t]{2}{*}{ Categories } & \multicolumn{2}{|c|}{ 1st grade } & \multicolumn{2}{|c|}{ 2nd grade } & \multicolumn{2}{|c|}{ 3rd grade } & \multicolumn{2}{|c|}{ 4th grade } & \multicolumn{2}{|c|}{ Total } \\
\hline & f & $\%$ & $\mathbf{f}$ & $\%$ & f & $\%$ & f & $\%$ & $\mathbf{f}$ & $\%$ \\
\hline $\begin{array}{l}\text { 1. Atomic and } \\
\text { subatomic particles }\end{array}$ & 149 & 22.6 & 108 & 23 & 67 & 18.2 & 134 & 31.2 & 458 & 23.8 \\
\hline Electron & 50 & 7.5 & 38 & 8.1 & 21 & 5.7 & 43 & 10 & & \\
\hline Proton & 50 & 7.5 & 34 & 7.2 & 21 & 5.7 & 42 & 9.6 & & \\
\hline Neutron & 45 & 6.8 & 33 & 7.1 & 19 & 5.2 & 42 & 9.6 & & \\
\hline Subatomic particles & 1 & 0.2 & 2 & 0.4 & 3 & 0.8 & 4 & 0.9 & & \\
\hline Quark & 1 & 0.2 & 0 & 0 & 2 & 0.5 & 1 & 0.7 & & \\
\hline Quantum fragments & 1 & 0.2 & 0 & 0 & 1 & 0.3 & 1 & 0.2 & & \\
\hline Nucleon & 0 & 0 & 1 & 0.2 & 0 & 0 & 0 & 0 & & \\
\hline Photon & 0 & 0 & 0 & 0 & 0 & 0 & 1 & 0.2 & & \\
\hline Photoelectric & 1 & 0.2 & 0 & 0 & 0 & 0 & 0 & 0 & & \\
\hline $\begin{array}{l}\text { 2. Structures formed } \\
\text { by the atom }\end{array}$ & 130 & 19.7 & 79 & 16.8 & 52 & 14.1 & 48 & 11.2 & 309 & 16.0 \\
\hline Element & 37 & 5.6 & 15 & 3.2 & 8 & 2.2 & 11 & 2.6 & & \\
\hline Molecule & 16 & 2.4 & 20 & 4.3 & 18 & 4.8 & 9 & 2.1 & & \\
\hline Compound & 30 & 4.5 & 8 & 1.7 & 1 & 0.3 & 4 & 0.9 & & \\
\hline Substance & 31 & 4.7 & 22 & 4.7 & 13 & 3.5 & 17 & 3.9 & & \\
\hline $\begin{array}{l}\text { Solid (stone, bullet, } \\
\text { soil, pencil) }\end{array}$ & 5 & 0.8 & 4 & 0.8 & 2 & 0.6 & 2 & 0.5 & & \\
\hline Living being (human) & 2 & 0.3 & 7 & 1.5 & 0 & 0 & 2 & 0.5 & & \\
\hline Universe & 2 & 0.3 & 2 & 0.4 & 3 & 0.8 & 2 & 0.5 & & \\
\hline Liquid (water, rain) & 2 & 0.3 & 0 & 0 & 3 & 0.8 & 0 & 0 & & \\
\hline Mixture & 3 & 0.5 & 1 & 0.2 & 0 & 0 & 1 & 0.2 & & \\
\hline Gas oil & 0 & 0 & 0 & 0 & 4 & 1.1 & 0 & 0 & & \\
\hline Acid-Base & 2 & 0.3 & 0 & 0 & 0 & 0 & 0 & 0 & & \\
\hline $\begin{array}{l}\text { 3. Structure of the } \\
\text { atom }\end{array}$ & 56 & 8.5 & 55 & 11.7 & 40 & 10.9 & 95 & 22.1 & 246 & 12.8 \\
\hline Nucleus & 11 & 1.6 & 25 & 5.4 & 16 & 4.2 & 32 & 7.4 & & \\
\hline Orbit & 11 & 1.6 & 17 & 3.6 & 7 & 1.9 & 32 & 7.4 & & \\
\hline Orbital (s,p,d,f) & 2 & 0.3 & 0 & 0 & 2 & 0.5 & 8 & 1.9 & & \\
\hline Sphere & 5 & 0.8 & 6 & 1.3 & 1 & 0.3 & 0 & 0 & & \\
\hline Indivisible & 4 & 0.5 & 0 & 0 & 7 & 1.9 & 4 & 0.9 & & \\
\hline Fissionable & 4 & 0.5 & 3 & 0.6 & 1 & 0.3 & 1 & 0.2 & & \\
\hline Period (A,B) & 7 & 1.1 & 0 & 0 & 0 & 0 & 1 & 0.2 & & \\
\hline Energy levels & 0 & 0 & 0 & 0 & 1 & 0.3 & 7 & 1.7 & & \\
\hline Voidage & 1 & 0.2 & 1 & 0.2 & 1 & 0.3 & 2 & 0.5 & & \\
\hline Gravitational force & 2 & 0.3 & 1 & 0.2 & 0 & 0 & 2 & 0.5 & & \\
\hline System & 2 & 0.3 & 0 & 0 & 0 & 0 & 2 & 0.5 & & \\
\hline Electron cloud & 1 & 0.2 & 2 & 0.4 & 1 & 0.3 & 2 & 0.5 & & \\
\hline Valence electron & 2 & 0.3 & 0 & 0 & 1 & 0.3 & 0 & 0 & & \\
\hline Induced & 1 & 0.2 & 0 & 0 & 0 & 0 & 1 & 0.2 & & \\
\hline
\end{tabular}




\begin{tabular}{|c|c|c|c|c|c|c|c|c|c|c|}
\hline \multicolumn{11}{|l|}{ Table 2.continued } \\
\hline \multirow[t]{2}{*}{ Categories } & \multicolumn{2}{|c|}{ 1st grade } & \multicolumn{2}{|c|}{ 2nd grade } & \multicolumn{2}{|c|}{ 3rd grade } & \multicolumn{2}{|c|}{ 4th grade } & \multicolumn{2}{|c|}{ Total } \\
\hline & f & $\%$ & $\mathbf{f}$ & $\%$ & $\mathbf{f}$ & $\%$ & f & $\%$ & f & $\%$ \\
\hline Uncertainty & 1 & 0.2 & 0 & 0 & 0 & 0 & 1 & 0.2 & & \\
\hline Lewis structure & 0 & 0 & 0 & 0 & 1 & 0.3 & 0 & 0 & & \\
\hline Determination & 1 & 0.2 & 0 & 0 & 0 & 0 & 0 & 0 & & \\
\hline Radiation & 1 & 0.2 & 0 & 0 & 0 & 0 & 0 & 0 & & \\
\hline Particle number & 0 & 0 & 0 & 0 & 1 & 0.3 & 0 & 0 & & \\
\hline $\begin{array}{l}\text { 4. Definition of the } \\
\text { atom }\end{array}$ & 74 & 11.2 & 57 & 12.2 & 45 & 12.2 & 36 & 8.4 & 212 & 11.0 \\
\hline The basic unit of matter & 27 & 4.1 & 24 & 5.2 & 17 & 4.6 & 15 & 3.5 & & \\
\hline Granular structure & 24 & 3.6 & 2 & 0.4 & 3 & 0.8 & 3 & 0.7 & & \\
\hline Smallest unit & 6 & 0.9 & 7 & 1.5 & 8 & 2.2 & 10 & 2.3 & & \\
\hline Particle & 11 & 1.7 & 6 & 1.3 & 9 & 2.4 & 3 & 0.7 & & \\
\hline Cell unit & 0 & 0 & 16 & 3.4 & 3 & 0.8 & 0 & 0 & & \\
\hline $\begin{array}{l}\text { The basic structure of } \\
\text { matter }\end{array}$ & 6 & 0.9 & 2 & 0.4 & 5 & 1.4 & 5 & 1.2 & & \\
\hline 5. Atom models & 49 & 7.4 & 42 & 9.0 & 72 & 19.6 & 48 & 11.2 & 211 & 10.9 \\
\hline Dalton's atomic model & 13 & 1.9 & 9 & 2 & 10 & 2.7 & 3 & 0.7 & & \\
\hline $\begin{array}{l}\text { Thomson's atomic } \\
\text { model }\end{array}$ & 7 & 1.1 & 7 & 1.5 & 15 & 4.1 & 6 & 1.4 & & \\
\hline Plum pudding model & 11 & 1.6 & 6 & 1.3 & 11 & 3 & 6 & 1.4 & & \\
\hline $\begin{array}{l}\text { Rutherford' atomic } \\
\text { model }\end{array}$ & 8 & 1.2 & 2 & 0.4 & 19 & 5.2 & 4 & 0.9 & & \\
\hline Bohr's atomic model & 7 & 1.1 & 7 & 1.6 & 10 & 2.7 & 4 & 0.9 & & \\
\hline Atomic models & 2 & 0.3 & 4 & 0.8 & 4 & 1.1 & 15 & 3.6 & & \\
\hline Modern atomic model & 0 & 0 & 2 & 0.4 & 2 & 0.5 & 5 & 1.2 & & \\
\hline Theory & 0 & 0 & 2 & 0.4 & 0 & 0 & 4 & 0.9 & & \\
\hline Gold foil experiment & 0 & 0 & 2 & 0.4 & 0 & 0 & 0 & 0 & & \\
\hline Alpha radiation & 1 & 0.2 & 0 & 0 & 1 & 0.3 & 0 & 0 & & \\
\hline Heisenberg & 0 & 0 & 1 & 0.2 & 0 & 0 & 0 & 0 & & \\
\hline Democritus & 0 & 0 & 0 & 0 & 0 & 0 & 1 & 0.2 & & \\
\hline $\begin{array}{l}\text { 6.Characteristics of } \\
\text { the atom }\end{array}$ & 80 & 12.0 & 38 & 8.1 & 25 & 6.8 & 38 & 8.8 & 181 & 9.4 \\
\hline $\begin{array}{l}\text { Chemical bond (ionic, } \\
\text { covalent, electro } \\
\text { negativity) }\end{array}$ & 15 & 2.2 & 8 & 1.7 & 3 & 0.8 & 4 & 0.9 & & \\
\hline Mass number & 13 & 1.9 & 11 & 2.3 & 4 & 1.2 & 3 & 0.7 & & \\
\hline $\begin{array}{l}\text { Electrolysis (anode, } \\
\text { cathode, anion, cation, } \\
\text { pole) }\end{array}$ & 7 & 1.1 & 6 & 1.3 & 3 & 0.8 & 6 & 1.4 & & \\
\hline Atomic number & 9 & 1.4 & 1 & 0.2 & 6 & 1.6 & 4 & 0.9 & & \\
\hline Ion/ionic charge & 5 & 0.8 & 9 & 2 & 2 & 0.5 & 3 & 0.7 & & \\
\hline $\begin{array}{l}\text { Mol / Avogadro's } \\
\text { number }\end{array}$ & 9 & 1.4 & 0 & 0 & 0 & 0 & 2 & 0.5 & & \\
\hline Atomic charge & 4 & 0.6 & 0 & 0 & 0 & 0 & 6 & 1.4 & & \\
\hline
\end{tabular}


Cross grade analysis of prospective science teachers' perceptions related to the concept of atom

\begin{tabular}{|c|c|c|c|c|c|c|c|c|c|c|}
\hline \multicolumn{11}{|l|}{ Table 2.continued } \\
\hline \multirow[t]{2}{*}{ Categories } & \multicolumn{2}{|c|}{ 1st grade } & \multicolumn{2}{|c|}{ 2nd grade } & \multicolumn{2}{|c|}{ 3rd grade } & \multicolumn{2}{|c|}{ 4th grade } & \multicolumn{2}{|c|}{ Total } \\
\hline & $\mathbf{f}$ & $\%$ & f & $\%$ & f & $\%$ & $\mathbf{f}$ & $\%$ & f & $\%$ \\
\hline Positive charge & 3 & 0.4 & 0 & 0 & 3 & 0.8 & 3 & 0.7 & & \\
\hline Negative charge & 3 & 0.4 & 0 & 0 & 3 & 0.8 & 3 & 0.7 & & \\
\hline Neutral & 3 & 0.4 & 0 & 0 & 0 & 0 & 2 & 0.5 & & \\
\hline Number of electrons & 2 & 0.3 & 2 & 0.4 & 1 & 0.3 & 1 & 0.2 & & \\
\hline Vibration & 3 & 0.4 & 0 & 0 & 0 & 0 & 0 & 0 & & \\
\hline Fission & 2 & 0.3 & 1 & 0.2 & 0 & 0 & 0 & 0 & & \\
\hline Number of neutron & 1 & 0.2 & 0 & 0 & 0 & 0 & 0 & 0 & & \\
\hline Atomic weight & 1 & 0.2 & 0 & 0 & 0 & 0 & 0 & 0 & & \\
\hline Spectral line & 0 & 0 & 0 & 0 & 0 & 0 & 1 & 0.2 & & \\
\hline 7. Nuclear structure & 23 & 3.5 & 23 & 4.9 & 23 & 6.3 & 4 & 0.9 & 73 & 3.8 \\
\hline Atomic bomb & 11 & 1.6 & 2 & 0.4 & 9 & 2.6 & 1 & 0.2 & & \\
\hline Energy /energy source & 1 & 0.2 & 5 & 1.2 & 2 & 0.5 & 2 & 0.5 & & \\
\hline $\begin{array}{l}\text { Nuclear disaster } \\
\text { (explosion, human } \\
\text { death, massacre, war) }\end{array}$ & 2 & 0.3 & 4 & 0.8 & 3 & 0.8 & 0 & 0 & & \\
\hline Nuclear power & 2 & 0.3 & 2 & 0.4 & 3 & 0.8 & 0 & 0 & & \\
\hline $\begin{array}{l}\text { Nuclear generating } \\
\text { countries (the United } \\
\text { States, Russia and } \\
\text { Japan) }\end{array}$ & 1 & 0.2 & 2 & 0.4 & 2 & 0.5 & 0 & 0 & & \\
\hline Fusion & 1 & 0.2 & 3 & 0.7 & 1 & 0.3 & 0 & 0 & & \\
\hline Fission & 2 & 0.3 & 2 & 0.4 & 1 & 0.3 & 0 & 0 & & \\
\hline $\begin{array}{l}\text { Nuclear accident } \\
\text { (Chernobyl, } \\
\text { Hiroshima, Nagasaki) }\end{array}$ & 3 & 0.4 & 1 & 0.2 & 0 & 0 & 0 & 0 & & \\
\hline Nuclear power station & 0 & 0 & 2 & 0.4 & 0 & 0 & 0 & 0 & & \\
\hline Nuclear weapon & 0 & 0 & 0 & 0 & 2 & 0.5 & 0 & 0 & & \\
\hline Radioactive & 0 & 0 & 0 & 0 & 0 & 0 & 1 & 0.2 & & \\
\hline $\begin{array}{l}\text { 8. Science and } \\
\text { scientific fields }\end{array}$ & 34 & 5.2 & 21 & 4.5 & 10 & 2.7 & 2 & 0.5 & 67 & 3.5 \\
\hline Chemistry & 12 & 1.8 & 11 & 2.5 & 3 & 0.8 & 1 & 0.25 & & \\
\hline Physics & 12 & 1.8 & 3 & 0.6 & 0 & 0 & 0 & 0 & & \\
\hline Science & 2 & 0.3 & 3 & 0.6 & 2 & 0.5 & 1 & 0.25 & & \\
\hline Biology & 4 & 0.6 & 0 & 0 & 1 & 0.3 & 0 & 0 & & \\
\hline Research/Investigation & 2 & 0.3 & 3 & 0.6 & 0 & 0 & 0 & 0 & & \\
\hline Science & 1 & 0.2 & 0 & 0 & 3 & 0.8 & 0 & 0 & & \\
\hline Experiment at Cern & 1 & 0.2 & 1 & 0.2 & 0 & 0 & 0 & 0 & & \\
\hline Engineering & 0 & 0 & 0 & 0 & 1 & 0.3 & 0 & 0 & & \\
\hline
\end{tabular}




\begin{tabular}{|c|c|c|c|c|c|c|c|c|c|c|}
\hline \multicolumn{11}{|l|}{ Table 2.continued } \\
\hline \multirow[t]{2}{*}{ Categories } & \multicolumn{2}{|c|}{ 1st grade } & \multicolumn{2}{|c|}{ 2nd grade } & \multicolumn{2}{|c|}{ 3rd grade } & \multicolumn{2}{|c|}{ 4th grade } & \multirow{2}{*}{\multicolumn{2}{|c|}{$\begin{array}{rr} & \text { Total } \\
\text { f } & \% \\
\end{array}$}} \\
\hline & f & $\%$ & f & $\%$ & f & $\%$ & f & $\%$ & & \\
\hline $\begin{array}{l}\text { 9. Dimensions of the } \\
\text { atom }\end{array}$ & 19 & 2.9 & 23 & 4.9 & 11 & 3.0 & 12 & 2.7 & 65 & 3.4 \\
\hline Small & 14 & 2.1 & 17 & 3.7 & 10 & 2.7 & 9 & 2 & & \\
\hline Atomic diameter/radius & 4 & 0.6 & 0 & 0 & 0 & 0 & 2 & 0.5 & & \\
\hline Invisible & 0 & 0 & 1 & 0.2 & 1 & 0.3 & 1 & 0.2 & & \\
\hline Microscopic & 1 & 0.2 & 2 & 0.4 & 0 & 0 & 0 & 0 & & \\
\hline $\begin{array}{l}\text { Compressing tiny } \\
\text { pieces }\end{array}$ & 0 & 0 & 1 & 0.2 & 0 & 0 & 0 & 0 & & \\
\hline Micro & 0 & 0 & 2 & 0.4 & 0 & 0 & 0 & 0 & & \\
\hline 10. Examples of atoms & 28 & 4.2 & 7 & 1.5 & 6 & 1.6 & 5 & 1.2 & 46 & 2.4 \\
\hline $\begin{array}{l}\text { Examples of atoms }(\mathrm{Cu} \\
\mathrm{Fe}, \mathrm{H}, \mathrm{O}, \mathrm{Pb}, \mathrm{N})\end{array}$ & 10 & 1.6 & 2 & 0.4 & 2 & 0.5 & 3 & 0.7 & & \\
\hline Periodic table & 9 & 1.3 & 2 & 0.4 & 4 & 1.1 & 2 & 0.5 & & \\
\hline Metal -nonmetal & 9 & 1.3 & 3 & 0.7 & 0 & 0 & 0 & 0 & & \\
\hline 11. Types of atoms & 6 & 0.9 & 9 & 1.9 & 8 & 2.2 & 5 & 1.2 & 28 & 1.4 \\
\hline Isotope & 4 & 0.6 & 3 & 0.63 & 5 & 1.4 & 0 & 0 & & \\
\hline Isotone & 0 & 0 & 3 & 0.63 & 2 & 0.5 & 4 & 1 & & \\
\hline Isobar & 0 & 0 & 3 & 0.63 & 1 & 0.3 & 1 & 0.2 & & \\
\hline Allotrope & 2 & 0.3 & 0 & 0 & 0 & 0 & 0 & 0 & & \\
\hline 12.Scientist & 9 & 1.4 & 4 & 0.9 & 7 & 1.9 & 1 & 0.2 & 21 & 1.1 \\
\hline Einstein & 8 & 1.2 & 2 & 0.45 & 7 & 1.9 & 1 & 0.2 & & \\
\hline Scientist & 0 & 0 & 2 & 0.45 & 0 & 0 & 0 & 0 & & \\
\hline Newton & 1 & 0.2 & 0 & 0 & 0 & 0 & 0 & 0 & & \\
\hline 13. Shape of the atom & 3 & 0.5 & 3 & 0.6 & 2 & 0.5 & 2 & 0.4 & 10 & 0.5 \\
\hline Round & 1 & 0.2 & 2 & 0.4 & 1 & 0.25 & 1 & 0.2 & & \\
\hline Spherical & 2 & 0.3 & 1 & 0.2 & 1 & 0.25 & 1 & 0.2 & & \\
\hline Total & 660 & 100 & 469 & 100 & 368 & 100 & 430 & 100 & 1927 & 100 \\
\hline
\end{tabular}

The prospective teachers associated a total of 110 concepts classified under 13 categories with the concept of atom. In Table 2, it was observed that the concepts associated with the concept of atom by the prospective teachers were mostly concepts related to subatomic particles, structures formed by the atom, structure of the atom, definition of the atom, and atom models. Additionally, it was also seen that, while less frequently, concepts related to characteristics of the atom, nuclear structure, science and scientific fields, dimensions of the atom, examples of atoms, types of atoms, scientists and the shape of the atom were also used.

In Table 2, it was observed that the most frequent category related to the concepts stated by the prospective teachers in all levels was "atomic and subatomic particles" $(23.8 \%)$, the concept variety regarding this category was the highest in the 4th year level. The prospective teachers stated the concepts of "electron, neutron, proton" most frequently regarding the category subatomic particles. These concepts were mentioned by more than half of the 1st and 2nd-year students, half of the 3rd-year students, and almost all 4th-year students. 
In all class levels, the "structures formed by the atom" category was the second category $(16 \%)$ to contain the highest number of associated concepts, while the concept variety related to this category decreased continually towards higher levels (Table 2). In relation to this category, the prospective teachers mostly stated the concepts "element, molecule, compound and substance". While these concepts were stated the least frequently by the 3rd-year students, the concept of molecule was the most frequently stated concept by almost half among the 3rdyear students (Table2).

In Table 2, the concept variety related to the "structure of the atom" category $(12.8 \%)$ was maximized in the 4th year. The most frequently stated concepts related to this category were "nucleus and orbit", and these were stated by more than half of all 4th-year students (Table 2). Additionally, concepts related to this category, "orbital and energy level", were stated mostly by a few students in the 4th year, and the concept "period" was stated by some students in the 1st year of their education.

The variety of the concepts related to the "definition of the atom" category stated by the prospective teachers $(11 \%)$ was no difference among the class levels. Regarding this category, the concepts "the basic unit of matter and cell unit" were most frequently mentioned by the 2nd-year students, the concept "granular structure" was stated mostly by the 1 styear students, and the concept "particle" was used mostly by the 3rdyear students.

Table 2 shows that the variety of the concepts related to the "atom models" category $(10.9 \%)$ was the highest in the 3rd year. Regarding this category, the concepts of "Thomson atom model (Thomson and plum pudding model), Rutherford atom model, Dalton atom model and Bohr atom model" were used most frequently by the 3rdyear students.

The variety of the concepts related to the "characteristics of the atom" category stated by the prospective teachers $(9.4 \%)$ was low, while it was the highest in the 1st-year students (Table 2). While the concepts "chemical bonds, mass number, electrolysis, atomic number, ion/ion charge, mole, atom charge (positive, negative, neutral)" were mentioned by the participants, they were mentioned by a small number of participants.

The variety of the concepts related to the "dimensions of the atom", "types of atoms", "shape of the atom", "nuclear structure", "science and scientific fields", and "scientist" categories stated by the participants were very low, and there was no difference among the class levels. It was identified that the dimension of the atom was associated with the "small" concept, and the shape of the atom was associated with the "spherical model" concept. It was also found that "atom bomb, nuclear disaster, nuclear accident, nuclear weapon" were the concepts that were most frequently stated in association with the category "nuclear structure", the concepts "chemistry, physics" were the most frequently stated ones in association with the category "science and branches of science", and "Einstein" was stated the most frequently in association with the category "scientist" (Table 2).

Table 3 shows the distribution of the sentences that the prospective science teachers formed in relation to the concept of "atom". 
Table 3.

Distribution of the sentences formed by the prospective teachers regarding the concept of atom based on semantic categories

\begin{tabular}{|c|c|c|c|c|c|c|c|c|c|c|}
\hline \multirow[t]{3}{*}{ Categories } & \multicolumn{10}{|c|}{ Concepts and Their Percentages } \\
\hline & \multicolumn{2}{|c|}{ 1st grade } & \multicolumn{2}{|c|}{ 2nd grade } & \multicolumn{2}{|c|}{ 3rd grade } & \multicolumn{2}{|c|}{ 4th grade } & \multicolumn{2}{|c|}{ Total } \\
\hline & f & $\%$ & f & $\%$ & $\mathbf{f}$ & $\%$ & $\mathbf{f}$ & $\%$ & $\mathbf{f}$ & $\%$ \\
\hline Scientific information & 94 & 47.5 & 59 & 41.9 & 40 & 38.8 & 73 & 56.6 & 266 & 46.5 \\
\hline Emotional information & 6 & 3 & 5 & 3.5 & 6 & 5.8 & 0 & 0 & 17 & 3 \\
\hline $\begin{array}{l}\text { Superficial information or } \\
\text { information that contains } \\
\text { examples from daily life }\end{array}$ & 32 & 16.2 & 30 & 21.3 & 25 & 24.3 & 21 & 16.3 & 108 & 19 \\
\hline $\begin{array}{l}\text { Unscientific information } \\
\text { or information with } \\
\text { misconceptions }\end{array}$ & 66 & 33.3 & 47 & 33.3 & 32 & 31.1 & 35 & 27.1 & 180 & 31.5 \\
\hline
\end{tabular}

Considering the distribution of the sentences formed by the prospective teachers regarding the concept of atom based on semantic categories, a large part of the sentences was in the scientific information category (46.5\%). While some (19\%) of the remaining responses were classified in the superficial information or information that contains examples from daily life category, a significant part $(31.5 \%)$ was classified in the non-scientific information or information that contains misconception category. The ratio of the sentences in the emotional information category was very low in all levels, and no responses in this category were found in the 4th year level (Table 3). The ratio of the sentences that were categorized as scientific information was the lowest in the 3 rd year, and the highest in the 4th year. It was also found that the numbers of sentences that contain superficial or daily-life examples were close in the 2 nd and 3rd year levels and a bit higher than those in other levels. Additionally, the numbers of sentences in the 1 st and 2nd year levels that contain non-scientific information and misconceptions were the highest, while this number was the lowest in the 4th year level. In the emotional information category in which the sentences with the lowest number were classified, it was observed that the close ratios of responses by the 1st, 2nd and 3rd year students were listed. Examples are provided below for the responses by the prospective teachers summarized in Table 3 based on the categories that are related to.

Some quotes in the scientific information category:

- The atom consists of protons, neutrons and electrons.(1st grade-30answers, 2nd grade-18 answers, 3rd grade-11 answers, 4th grade-21 answers).

- Electrons are negatively charged, protons are positively charged, and neutrons are uncharged particles.(1st grade-6 answers, 2nd-1 answer, 3rd grade-5 answers, 4th grade-5 answers).

- Neutrons and protons are found in the nucleus, while electrons are found in the orbit.(1st grade-11 answers, 2nd grade-9 answers, 3rd grade-9 answers, 4th grade-12 answers).

- Thomson liked the atom to plum pudding. An atom has positive and negative charges within.(1st grade-3 answers, 2nd grade-2 answers, 3rd grade-3 answers, 4th grade-5 answers).

- Elements on the periodic table are listed based on their atomic numbers. The elements are categorized as metals, nonmetals, and transition metals.(1st 
Cross grade analysis of prospective science teachers' perceptions related to the concept of atom

grade-4 answers, 2nd grade-1 answer, 3rd grade-1 answer, 4th grade-1 answer).

- $\quad$ There are energy levels in the atom.(4th grade-7 answers).

- The sum of the number of protons and neutrons gives the atomic mass number.(1st grade-5 answers, 2nd-2 answers, 4th grade-2 answers)

- If the number of protons is the same in atoms, they are isotopes; if the number of neutrons is the same, they are isotones; if the mass number is the same, they are isobars.(1st grade-2 answers, 2nd grade-5 answers, 3rd grade- 4 answers, 4 th grade-1 answer).

- Atoms form ionic and covalent bonds among each other.(1st grade-5 answers, 2nd grade-2 answers, 3rd grade-1 answer, 4th grade-1 answer).

- Elements or compounds are formed by the gathering of atoms. (1st grade-11 answers, 2nd grade-4answers, 3rd grade-2 answers, 4th grade-7 answers).

- Quarks are subatomic particles. (3rd grade-2 answers).

- The atom has a hollow structure. (3rd grade-1 answer, 4th grade-1 answer).

Some quotes in the emotional information category:

- An atom bomb has the power to destroy a country. (1st grade-2 answers, 2nd grade-2 answers, 3rd grade-2 answers).

- Very dangerous bombs and acidic poisons can be made from atoms. (1st grade-1 answer).

- The effects of the Chernobyl disaster in Russia are still going on. (1st grade-1 answer, 2nd grade-1 answer, 3rd grade-1 answer).

- An atom bomb has a substantial effect on living areas as it is disintegrated by a very large energy. (1st grade-1 answer, 3rd grade-2 answers).

- The subject of atoms concerns me a lot. (1st grade-1 answer, 2nd grade-1 answer).

Some quotes in the information containing superficial or daily life examples category:

- Various scientists such as Dalton, Bohr, Rutherford, and Thomson have atom theories and research. (1st grade- 6 answers, 2nd grade- 5 answers, 3rd grade-14 answers, 4th grade-6 answers).

- The atom is the common subject of the physics and chemistry classes. (1st grade-5 answers).

- The atom is a subject of chemistry. (2nd grade-5 answers).

- There are many different elements in the nature. (1st grade- 3 answers).

- They are microscopic particles, and they form different shapes and sizes of substances. (3rd grade-1 answer, 4th grade-1 answer).

Some quotes in the unscientific information or information with misconceptions category:

- The atom is the smallest basic unit of matter. (1st grade-39 answers, 2nd grade-33 answers, 3rd grade-11 answers, 4th grade-23 answers).

- It is the smallest, indivisible part of matter, an atom cannot be divided. (1st grade-3 answers, 3rd grade-4 answers, 4 th grade- 3 answers).

- There are electrons, protons and neutrons in an atom's nucleus. (1st grade-5 answers, 2nd grade- 2 answers, 3rd grade-2 answers, 4th grade- 3 answers). 
- The positive pole is proton, the negative pole is electron, and the neutral pole is neutron. (1st grade-1 answer).

- By dividing the atom, Einstein proved that it has the basic unit called electron, proton and neutron. (1st grade-3 answers, 2 nd grade-2 answers, 3rd grade-3 answers).

- The atom's nucleus consists of neutrons, electrons and protons, and these are found in the orbits. (1.st grade- 2 answers, 2 nd grade- 4 answers).

- The cell is the smallest unit of living beings. (2nd grade-4 answers).

The examples of quotes above show that prospective teachers on different levels use similar sentences that have the quality of being acceptable in a scientific sense. For example, considering the statements in the scientific information category, in which the highest number of responses was classified, the statement "the atom consists of protons and neutrons in the nucleus and electrons in the orbit" was frequently repeated by prospective teachers on different levels. Additionally, it was also seen that prospective teachers $(31.5 \%)$ gave answers in the category of unscientific information or information based on misconception, and used the expression "the atom is the smallest unit of matter". Considering the examples in other categories, while similar responses were found, the responses varied in general. In this context, while similar unscientific and misconception-based responses were found on different levels, such responses were rarer for other categories.

\section{CONCLUSION, DISCUSSION and RECOMMENDATIONS}

In the scope of this study, the concepts prospective teachers associated with the concept of atom were revealed using a word association test, the perceptions of the participants regarding this concept were analyzed, and the change in these perceptions along the undergraduate program was investigated.

It was observed that the concepts associated with the concept of atom by the prospective teachers were mostly concepts related to subatomic particles, structures formed by the atom, structure of the atom, definition of the atom, and atom models. Additionally, concepts related to characteristics of the atom, nuclear structure, science and scientific fields, dimensions of the atom, examples of atom, atom type, scientists and the shape of the atom were also mentioned.

It was seen that the most frequently mentioned concepts among participants of all levels were related to the "atomic and subatomic particles" category, and in the scope of this category, the concepts "electron, proton and neutron" were mentioned mostly. These concepts are the basic physical concepts about the atom, and they were mentioned by more than half of the 1st and 2ndyear students, half of the 3rdyear students and almost all 4thyear students. The decrease in these concepts' frequency of expression and the minimum state reached in the 3rdyear students may be an indicator that this learning is not permanent, or it may be that there is no course in the 3rd year science education curriculum in which these concepts are discussed. While the increase in the 4th year level may be explained by preparation for KPSS, it may also be explained by the elective chemistry and life sciences courses taken in the 4th year. Additionally, at all levels of education, it was seen that concepts like quark, nucleon, photon, and photoelectric that are related to the subatomic particles category were rarely mentioned. It is an interesting finding that these concepts were rarely or sometimes never 
mentioned by the 2nd year prospective teachers, although there is a course on introduction to modern physics in the 2 nd year science education curriculum.

The participants in all class levels mentioned concepts related to the "structures formed by the atom" category by $16 \%$, mostly the concepts "element, molecule, compound and matter" were mentioned, and the concept variety in this category decreased continually towards higher levels. The finding that about half of the participants in the 1st year had more variety in their statements of concepts in comparison to other levels may be explained by their recent completion of preparation for entrance exams and possession of fresh knowledge.

Similarly, participants in all class levels stated concepts related to the "structure of the atom" category $(12.8 \%)$, they mentioned the concepts "nucleus and orbit" mostly. The finding that concepts such as orbital, energy level, hollow structure and electron cloud were mentioned generally by 4th-year students may be explained by their preparation for KPSS subject exams, as well as elective courses they might have taken such as chemistry and life sciences.

The concepts stated in relation to the "description of the atom" category in all class levels $(11 \%)$ varied to the broadest extent in the 1 st year, and this variation gradually decreased along higher levels. In the scope of this category, the participants mentioned the concepts of "the basic unit of matter, granular/particular structure, smallest unit, particle, cell unit, the most fundamental unit of matter". The concept of "the basic unit of matter" was used most frequently by 2ndyear students, and the term "cell unit" was used only by 2 ndyear students, which may be explained by the general biology course included in the 2 nd year science education curriculum. Additionally, the finding that the 1styear students were the ones who mentioned the concept "granular structure" most frequently may be associated with the general chemistry course in the 1st year science education curriculum. Another finding that the concept "particle" was mentioned most frequently by 3rdyear students may be explained by courses such as selected topics in physics in the 3rd year science education curriculum.

While the variety of the concepts related to the "atom models" category mentioned by all participants (10.9\%) was the highest in the 3rd year, it was found that the Thomson atom model relevant to this category was the most frequently mentioned model in all class levels, and this was followed by the Rutherford atom model. Karagöz and SağlamArslan (2012) stated that students usually associate the atom with foods, and reached the conclusion that students' descriptions are influenced by Thomson's plum pudding model and the granular model by Rutherford what particles revolve around a nucleus learned from science teachers or depictions in textbooks. Harrison and Treagust (1996) reported that cognitive models that students have about the atom are affected by textbooks and models used by teachers. Moreover, these concepts were followed by the Dalton, Bohr and modern atom models. It was observed that the Dalton model was the second most frequently mentioned concept in the 1st and 2nd year and the modern model was not mentioned at all. This result supports the findings of Paliç-Şadoğlu (2016). Likewise, Çökelez and Yalçın (2012) also reported that more than half of students think about the atom as a solid sphere, and a very small proportion (5\%) is aware of modern atom theory depictions. Furthermore, considering the study by PolatYaseen (2012) which suggested that middle-school students usually have drawings of the Dalton model, it may be argued that some participants of this study still retained the 
conceptual outcomes of the educational process in the elementary and middle-school periods. Additionally, it was seen that the concept of the modern atom model was mentioned usually by the 4thyear students despite its rare expression by others, and this was associated by the 4thyear students' preparation process for KPSS subject exams.

The variety of the concepts related to the "characteristics of the atom" category stated by the prospective teachers was low and the concepts "chemical bonds, mass number, electrolysis, atomic number, ion/ion charge, mole, atom charge (positive, negative, neutral)" were mentioned mostly by the 1st-year students, while these were rarely mentioned in general. Similarly, the variety of the concepts related to the "examples of atoms" category stated by the participants was very low, and the highest among the 1styear students. It was also observed that the concept variety in other categories with low percentages was low and did not show any noticeable difference based on class levels.

In the scope of this study, the prospective teachers were asked to form sentences about the concepts they associated with the atom, and the sentences formed by the participants were classified under four categories based on their qualities. Accordingly, it was seen that a little under half of the sentences formed by the participants was in the scientific information category and the participants formed similar sentences in general. The ratio of the sentences considered to be scientific information decreased in higher levels was minimized in the 3rd year level, and maximized in the 4th year level. Likewise, this situation is supported by the finding that concept variety was the highest in the 1st year, decreased in the 2nd and 3rd years, and increased again in the 4th year. Decrease in concept variety in the 3rd year implies that the obtained knowledge was not permanent, and learning was superficial. This situation, which is in favor of the 1st and 4thyear students, may be associated with the existence of nation-wide examinations seen at the level of both class levels.

Another part of the sentences formed by the participants was in the category of information on examples from superficial or daily-life issues, while a significant proportion was considered to be in the category of information that contains nonscientific basis or misconceptions. While similar sentence qualities were seen in these categories, it was seen that the responses started to differentiate in general. Additionally, it was found that the ratio of sentences in the emotional information category was very low for all class levels, while no sentence of this category was found at the level of 4 th year.

In the statements in the category of unscientific information or information based on misconception, the most frequently provided statement by many prospective teachers was "the atom is the smallest unit of matter." Similarly, Kaya (2010) interpreted the responses of 3rd-year science education students as "the atom is the smallest unit of matter" in the "partial comprehension" category. In Birinci-Konur and Ayas study (2008), a misconception as "the smallest unit of matter is the atom" was found. The statement that "the atom is the smallest unit of matter" is a misconception that may lead students to think that "the atom is indivisible," and therefore, students experience confusion when they see the structure and components of the atom (Bak \& Ayas, 2008). Additionally, some studies in the literature (Kırbaşlar, Özsoy-Güneş, Avc1 \& Atalar, 2012) also suggest that the statement "the atom is the smallest unit that carries the characteristics of the matter" may lead to a perception that there are no smaller particles in the atom. 
On the other hand, only 2ndyear students were seen to associate the atom with "cell unit" and "microscopic" concepts and establish similarity between the atom and cells. This may be explained by the general biology course offered in the 2nd year science education curriculum. Kaya (2012) reported that some students have misconceptions that "the atom is the smallest, indivisible unit of matter" and "the atom is the most fundamental and basic unit of a cell”. In Özgür and Bostan's study (2007), it was reported that smallness of atom and molecules and observation of a cell via a microscope makes student perceptions harder, some students consider atoms and cells to have the same dimensions, and this misconception is led by the definitions of atoms and cells.

Based on the comprehensive interpretation of the results obtained from the study, it may be seen that prospective teachers have significant shortcomings and difficulties in structuring their perceptions in an explanatory and scientifically acceptable way regarding the concept of atom which has an important place among the concepts that they will teach in the future. This situation brings the qualities of education situations into question, regarding the teaching of the concept of atom, which is discussed from the middle-school 6th grade level to the last years of undergraduate study, and has an interdisciplinary nature. Additionally, it is recommended to analyze and improve how the atom is discussed in different disciplines and at different levels, which education situations are utilized, and whether these are internally consistent and complementary to each other. The studies that focus on the design and implementation of learning environments for identifying and developing perceptions of the atomic concept of prospective teachers in different disciplines will contribute to the field. 


\section{REFERENCES}

Akıllı, M. (2011). Fen bilgisi eğitimi 2. sinıf öğrencilerine atomun yapısı konusunun 3D bilgisayar modelleri yardımıyla ögretimi. Yayımlanmamış doktora tezi, Atatürk Üniversitesi, Erzurum.

Akyol, D. (2009). Fen alanında öğrenim gören üniversite ögrencilerinin zihinlerindeki atom modellerinin incelenmesi. Yayımlanmamış yüksek lisans tezi, Dokuz Eylül Üniversitesi, İzmir.

Atabek Yiğit, E. (2016). Kelime ilişkilendirme testi aracılığıyla bazı temel kimya kavramları konusundaki bilişsel yapının araştırılması. Illköğretim Online, 15(4), $1385-1398$.

Ayaz, E., Karakaş, H. ve Sarıkaya, R. (2016). Sınıf öğretmeni adaylarının nükleer enerji kavramına yönelik düşünceleri: Bağımsız kelime ilişkilendirme örneği. Cumhuriyet Üniversitesi Fen Fakültesi Fen Bilimleri Dergisi, 37, 42-54.

Ayvacı, H.Ş. ve Devecioğlu, Y. (2009). İlköğretim öğrencilerinin iş-güç-enerji konusunda sahip oldukları yanlış anlamalar. The First International Congress of Educational Research Association,1-3 Mayıs, Çanakkale, Turkey.

Bahar, M., Gündüz, S. ve Doğan, S. (2006). Bilim tarihine kısa bir bakış. İçinde (Ed.: Mehmet Bahar). Fen ve Teknoloji Öğretimi. Ankara: Pegem A Yayıncılık.

Bahar, M., Johnstone, A.H. \& Sutcliffe, R.G. (1999). Investigation of students' cognitive structure in elementary genetics through word association tests. Journal of Biological Education, 33(3), 134-141.

Bahar, M. ve Özatlı, N.S. (2003). Kelime iletişim test yöntemi ile lise 1. sınıf öğrencilerinin canlıların temel bileşenleri konusundaki bilişsel yapılarının araştırılması. Balıkesir Üniversitesi Fen Bilimleri Enstitüsü Dergisi, 5(2), 7585 .

Bak, Z. ve Ayas, A. (2008). Kimya öğrencilerinin atom kavramını anlama düzeylerinin kavram haritası yöntemiyle belirlenmesi. 8. Uluslararası Eğitim Teknolojileri Konferans1, 6-9 Mayıs, Anadolu Üniversitesi, Eskişehir.

Baybars, M.G. ve Küçüközer, H. (2014). Fen bilgisi öğretmen adaylarının atom kavramına ilişkin kavramsal anlama düzeyleri. Journal of Research in Educational and Teaching, 3(4), 405-417.

Ben-Zvi, R.,Eylon, B. \& Silberstein, J. (1986). Is an Atom of copper Malleable?.Journal of Chemical Education, 63, 64-66.

Birinci-Konur, K. \& Ayas, A. (2008). Sınıf öğretmeni adaylarının bazı kimya kavramlarını anlama seviyeleri. Kastamonu Ĕ̆itim Dergisi, 16(1), 83-90.

Bradley, J. D. \& Mosimege, M.D. (1998). Misconceptions in acids and bases: a comparative study of student teachers with different chemistry backgrounds. South African Journal of Chemistry, 51(3), 137-145.

Çökelez, A. \& Dumon, A. (2005). Atom and molecule: upper secondary school French students' representations in long-term memory. Chemistry Education Research and Practice, 6(3), 119-135. 
Clement, J. (1982). Students' preconceptions in introductory mechanics. American Journal of Physics, 50(1), 66-70.

Çalıklar, Ş. (2015). Atom kuramlarının öğretiminde ögrencilerin akademik başarıları, epistemolojik inançları ve ögrenmelerinin kalıcılı̆̆ üzerine ögrenci takımlar başarı bölümleri ve takım oyun turnuva yönteminin etkisi. Yayımlanmamış yüksek lisans tezi, Atatürk Üniversitesi, Erzurum.

Çökelez, A. ve Yalçın, S. (2012). İlköğretim 7. sınıf öğrencilerinin atom kavramı ile ilgili zihinsel modellerinin incelenmesi. Illkögretim Online, 11(2), 452-471.

Demirci, S., Yılmaz, A. ve Şahin, E. (2016). Lise ve üniversite öğrencilerinin atomun yapısı ile ilgili zihinsel modellerine genel bir bakış. Journal of the Turkish Chemical Society, 1(1), 87-106.

Demircioğlu, G., Altuntaş Aydın, M. ve Demirci, H. (2012). Kavramsal değişim metninin ve üç boyutlu modelin 7. sınıf öğrencilerinin atomun yapısını anlamalarına etkisi. Bayburt Ĕgitim Fakültesi Dergisi, 7(2),70-96.

Doymuş, K.,Koç, Y., Akkuş, A., Başaran, F. ve Zorlu, Y. (2012). Fen eğitimi alan öğrencilerin s, p ve d orbitalleri anlama düzeyleri. Erzincan Üniversitesi Fen Bilimleri Enstitüsü Dergisi,5(2), 151-163.

Ekici, G. ve Kurt, H. (2014). Öğretmen adaylarının “aids” kavramı konusundaki bilişsel yapıları: Bağımsız kelime ilişkilendirme testi örneği. Türkiye Sosyal Araştırmalar Dergisi, 183, 267-306.

Ekici, G., Gökmen, A. ve Kurt, H. (2014).Öğretmen adaylarının "bilgisayar” kavramı konusundaki bilişsel yapılarının belirlenmesi. Gazi Üniversitesi Gazi Eğitim Fakültesi Dergisi, 34(3), 359-405.

Ercan, F.,Taşdere, A. \& Ercan, N. (2010). Observation of cognitive structure and conceptual changes through word association tests. Journal of Turkish Science Education,7(2), 136-154.

Gökçek, T. (2009). Durum çalışması değerlendirmelerinin uygulaması. Çeviri: Davey, L. (1991). The application of case study evaluations. Practical Assessment, Research \& Evaluation, Illkögretim Online, 8(2), 1-3.

Griffiths, A. K. \& Preston, A.K. (1992). Grade-12 students' misconceptions relating to fundamental characteristics of atom sand molecules. Journal of Research in Science Teaching, 29(6), 611-628.

Gussarsky, E. \& Gorodetsky, M. (1990). On the concept chemical equilibrium: The associative framework. Journal of Research in Science Teaching, 27(3), 197204.

Güneş, H. ve Gözüm, A. İ.C. (2013). İlköğretimde işlenen ekoloji konusunun 10. sınıf ögrencilerin ekosistem ekolojisi konusundaki hazırbulunuşluk düzeyleri üzerindeki etkisinin saptanmasında kelime ilişkilendirmenin kullanılmasl. Eğitim ve Öğretim Araştırmaları Dergisi, 2(3), 252-264.

Harrison, A.G. \& Treagust, D.F. (1996). Secondary students' mental models of atoms and molecules: implications for teaching chemistry. Science Education, 80(5), 509534. 
Hovardas, T. \& Korfiatis, K.J. (2006). Word associations as a tool for assessing conceptual change in science education. Learning and Instruction, 16, 416432.

Justi, R. \& Jilbert, J. (2000). History and philosophy of science through models: some challenges in the case of the atom. International Journal of Science Education, 22(9), 993-1009.

Kahraman, S. ve Demir, Y. (2011). Bilgisayar destekli 3D öğretim materyallerinin kavram yanılgıları üzerindeki etkisi: Atomun yapısı ve orbitaller. Erzincan Eğitim Fakültesi Dergisi, 13(1), 173-188.

Karagöz, Ö. ve Sağlam Arslan, A. (2012). İlköğretim öğrencilerinin atomun yapısına ilișkin zihinsel modellerinin analizi. Türk Fen Eğitimi Dergisi, 9(1), 132-142.

Kaya, A. (2010). Fen bilgisi öğretmen adaylarının ışık ve atom kavramlarını anlama seviyelerinin tespiti. Erzincan Eğitim Fakültesi Dergisi, 12(1), 15-37.

Kaya, M.F. ve Taşdere, A. (2016).İlkokul Türkçe eğitimi için alternatif bir ölçme değerlendirme tekniği: Kelime ilişkilendirme testi. Turkish Studies, International Periodical for the Languages, Literature and History of Turkish or Turkic, 11(9), 803-820.

Kırbaşlar, F.G., Özsoy-Güneş, Z., Avcı, F. ve Atalar, A. (2012). Fen ve teknoloji ders kitaplarında "madde ve değişim" öğrenme alanındaki bazı kavramların ve örneklendirmelerin incelenmesi. Hasan Ali Yücel Eğitim Fakültesi Dergisi, 9(2), 61-83.

Kırbaşlar, F.G., Özsoy-Güneş, Z., Avcı, F. ve Atalar, A. (2012).

Kurt, H.\& Ekici, G. (2013a).What is a virus? Prospective biology teachers' cognitive structure on the concept of virus. International Online Journal of Educational Sciences, 5(3), 736-756.

Kurt, H. ve Ekici, G. (2013b). Biyoloji öğretmen adaylarının bağımsız kelime ilişkilendirme testi ve çizme-yazma tekniğiyle "osmoz" kavramı konusundaki bilişsel yapılarının belirlenmesi. Turkish Studies, International Periodical for the Languages, Literature and History of Turkish or Turkic, 8(12), 809-829.

Nakiboğlu, C., Karakoç, Ö. ve Benlikaya, R. (2002). Öğretmen adaylarının atomun yapısı ile ilgili zihinsel modelleri. Abant İzet Baysal Üniversitesi Eğitim Fakültesi Dergisi, 2(2), 88-98.

Nakiboglu, C. (2008). Using word associations for assessing nonmajor science students' knowledge structure before and after general chemistry instructions: The case of atomic structure. Chemical Educational Research Practice, 9, 309-322.

ÖzataYücel, E. \& Özkan, M. (2015). Determination of secondary school students' cognitive structure, and misconception in ecological concepts through word association test. Educational Research and Reviews, 10(5), 660-674.

ÖzataYücel, E. \& Özkan, M. (2016). Determining the perceptions of pre-service science teachers regarding environmental problems through word association. International Journal of Learning and Teaching, 8(3), 164-173. 
Cross grade analysis of prospective science teachers' perceptions related to the concept of atom

Özata Yücel, E. ve Özkan, M. (2014). Fen bilimleri öğretmen adaylarının çevre algılarının kelime ilişkilendirme aracılığıyla belirlenmesi. e-Uluslararası Eğitim Araştırmaları Dergisi, 5(4), 41-56.

Özgür, S. ve Bostan, A. (2007). Atom kavramını epistemolojik analizi ve öğrencilerin konu ile ilgili kavram yanılgılarının karşılaştırılması. e-Journal of New World Sciences Academy, 2(3), 214-231.

Paliç Şadoğlu, G. (2016). Fen bilgisi öğretmen adaylarının atom kavramına ilişkin düşüncelerinin çizme-yazma tekniği ile belirlenmesi. 1. Uluslararası Akademik Araştırmalar Kongresi, Bildiriler kitabı içinde (ss.3592-3598).

Park, E. J. \& Light, G. (2009). Identifying atomic structure as a threshold concept: Student mental models and troublesomeness. International Journal of Science Education, 31(2), 233-258.

Polat-Yaseen, Z. (2012, December). A comparison between elementary school students' mental models and visualizations in textbooks for the concept of atom. AAREAPERA International Conference, Sydney.

Pringle, R.M. (2004). Making it visual: Creating a model of the atom. Science Activities, 40(4), 30-33.

Sağlam Arslan, A. (2016). Didaktiğin antropolojik teorisi. İçinde (Ed: Bingölbali,E., Arslan, S. \& Zembat, İ.Ö.). Matematik eğitiminde teoriler. Ankara: Pegem Akademi Yayıncılık.

Schulte, P.L. (2001). Preservice primary teacher alternative conceptions in science and attitudes toward teaching science. Unpublished Doctoral Dissertation, University of New Orleans, New Orleans.

Taylan-Yıldız, H. (2006). Ilköğretim ve ortaöğretim öğrencilerinin atomun yapısı ile ilgili zihinsel modelleri. Yayımlanmamış yüksek lisans tezi, Balıkesir Üniversitesi, Balıkesir.

Tezcan, H. ve Çelik, T. (2009). Kimya öğretmen adaylarının atomla ilgili bazı kavramları anlama derecelerinin belirlenmesi. Türk Ĕ̈itim Bilimleri Dergisi, 7(1), 49-67.

Tsaparlis, G. (1997). Atomic orbitals, molecular orbitals and related concepts: Conceptual difficulties among chemistry students. Research in Science Education, 27(2), 271-287.

Tsaparlis, G. \& Papaphotis, G. (2009). High school students' conceptual difficulties and attempts at conceptual change: The case of basic quantum chemical concepts. International Journal of Science Education, 31(7), 895-930.

Yağbasan, R. ve Gülçiçek, Ç. (2003). Fen öğretiminde kavram yanılgılarının karakteristiklerinin tanımlanması. Pamukkale Üniversitesi Eğitim Fakültesi Dergisi, 1(13), 102-120.

Yıldırım, A. ve Şimşek, H. (2011). Sosyal bilimlerde nitel araştırma yöntemleri. Ankara: Seçkin Yayıncılık. 


\section{GENIŞ ÖZET}

\section{Giris}

Öğrencilerin ortaokuldan üniversiteye kadar farklı seviyelerde belirli aralıklarla karşı karşıya kaldıkları atom kavramı, bilindiği üzere temel fen kavramları arasında yer almaktadır. Maddenin yapısının açıklanmasında temel teşkil eden atomun, farklı disiplinlerdeki hatta gerçek yaşamdaki rolü dikkate alındığında bu kavramla ilgili yürütülen öğretim faaliyetlerinin önemi açık bir şekilde görülmektedir. Soyut ve açıklanması zor yapısı nedeniyle atom ve atoma ilişkin kavramların öğretilmesi birçok araştırmanın konusu olmuştur. Yapılan çalışmaların bütüncül analizi mikroskobik ve soyut yapısından dolayı atomun anlaşılması ve açıklanması zor bir kavram olarak nitelendirildiğini, bu nedenle de öğrencilerin atom ve ilişkili kavramları yanlış anladıkları ve bu kavramı öğrenmede güçlük çektikleri, çeşitli alternatif kavrama veya kavram yanılgısına sahip olduklarını ortaya koymaktadır.

Bilindiği gibi güncel öğretim teorilerinin tamamının desteklediği ortak iddiaya göre öğrencilerin öğrenme ortamına geldiklerinde sahip oldukları ön bilgiler (kavram yanılgılarını, alternatif kavramları, vb. içeren), etkili ve bilimsel öğrenmeye engel olabilecek niteliktedir. Öğrenme bireyin zihninde var olan mevcut kavramlar ile yeni öğrenilen kavramlar arasındaki etkileşimin bir ürünü olduğundan, öğrencilerin zihinlerinde yer alan kavramların genel özelliklerinin ortaya konulması gerekmektedir.

$\mathrm{Bu}$ çalışmanın amacı ileri seviyedeki fen bilimleri konularının doğru ve kolay bir biçimde algılanmasına ve dolayısıyla anlamlı öğrenmelerin gerçekleşmesine olanak sağlayacak atom kavramına yönelik öğretmen adaylarının algılamalarını tespit etmek ve lisans programlarının bu algılamalar üzerindeki etkilerini belirlemek olarak tanımlanmıştır. Bu amaçla ilişkili olarak aşağıdaki sorulara cevap aranmıştır;

- Fen bilgisi öğretmen adayları atom kavramını hangi konu ve/veya kavramlarla ilişkilendiriyorlar ve ilişkilendirilen bu konu ve/veya kavramlar sınıf seviyesine göre nasıl değişim göstermektedir?

- Fen bilgisi öğretmen adayları atom kavramı ile ilişkili konu ve/veya kavramaları nasıl açıklıyorlar ve bu açıklamaların bilimsel nitelikleri sınıf seviyelerine göre nasıl farklılaşmaktadır?

\section{Yöntem}

Durum çalışması olarak yürütülen bu çalışma kapsamında gerçek ortamda neler olduğu sistematik bir biçimde veriler toplanarak analiz edilmiş ve sonuçlar ortaya konulmuştur. Çalışmanın örneklemini fen bilgisi öğretmenliği bölümünde öğrenim gören 66birinci sınıf, 47 ikinci sınıf, 38 üçüncü sınıf ve 43dördüncü sınıf olmak üzere toplam 194 öğretmen adayı oluşturmaktadır. Bir kavrama ait öğrenmelerin, o kavramın öğretim durumları ile ilişkili olduğu hatta öğrenmelerin, karşı karşıya kalınan öğretimlerin bir yansıması olduğu gerçeği dikkate alınarak temelleri atılan Didaktiğin Antropolojik Teorisinin temel kabulleri çerçevesinde bu çalışma kapsamında katılımcıların atom kavramı ile ilgili olası bilgileri analiz edilmiştir.

$\mathrm{Bu}$ çalışmada veri toplama aracı olarak kelime ilişkilendirme testi kullanılmışıtır. Kelime ilişkilendirme testinin ilk aşamasında fen bilgisi öğretmen adaylarının atom 
kavramı ile ilişkilendirdikleri kelime ve kavramlar ortak özellikleri dikkate alınarak kategorilendirilmiş ve frekans tablosu oluşturulmuştur. Fen bilgisi öğretmen adaylarının kelime ilişkilendirme testinin ikinci aşamasında atom kavramı ile ilişkilendirdikleri kelime veya kavramlar için yazdıkları cümleler ise içerdikleri anlamlara göre ÖzataYücel ve Özkan (2015) tarafından geliştirilen kategorilere göre değerlendirilerek sinıflandirılmıştır.

Veri analizi aşamasında güvenirlik çalışmaları kapsamında bir araştırmacı tarafından katılımcıların atom kavramını ilişkilendirdikleri kelime veya kavramlara ait kategoriler belirlenmiş, diğer araştırmacı tarafından ise verilerin analizi kontrol edilmiştir. Katılımcıların atom kavramı ile ilişkilendirdikleri kelime veya kavramların içerdikleri anlamlara göre analizi aşamasında ise, çalışmayı gerçekleştiren araştırmacıların her biri kağıtları ayrı ayrı incelemiş ve sınıflandırma yaptıktan sonra; ortak olanlar kabul edilip, farklılık gösterenler ise tekrar gözden geçirilerek sınıflandırılmıştır.

\section{Bulgular, Tartışma ve Sonuç}

Bu çalışmada öğretmen adaylarının atom kavramını ilişkilendirdikleri kavramlar kelime ilişkilendirme testi aracılığıyla ortaya konularak, adayların atom kavramına ait algıları analiz edilmiş ve bu algıların lisans öğrenimi süresince değişimi incelenmiştir. Öğretmen adaylarının atom kavramına yönelik ifade ettikleri kelimeler/kavramlar 110 kavram olarak belirlenmiş ve 13 kategoride toplanmıştır. Öğretmen adaylarının atom kavramını, çoğunlukla atom ve atom altı parçacıklar, atomun oluşturduğu yapılar, atomun yapısı, atomun tanımı ve atom modelleri ile ilişkilendirdikleri belirlenmiştir. Diğer taraftan öğretmen adaylarının atomu, atomun özellikleri, nükleer yapı, bilim ve bilim dalları, atomun boyutu, atom örnekleri, atom çeşitleri, bilim insanı ve atomun şekli ile de ilişskilendirdikleri görülmüştür.

Tüm sınıf seviyelerindeki öğretmen adaylarının belirttiği kavramların en fazla "atom ve atom altı parçacıklar" kategorisiyle ilişkili olduğu ve bu kategoriyle ilişkili kavram çeşitliliğinin en fazla 4. sınıflarda olduğu görülmüştür. Öğretmen adayları tarafindan "atom ve atom altı parçacıklar" kategorisiyle ilişkili olarak çoğunlukla "elektron, proton ve nötron" kavramları ifade edilmiştir. Adaylar tarafından ifade edilen "atomun tanımı" kategorisiyle ilişkili olan kavram çeşitliliğinin sınıf seviyelerinde pek farklılık göstermediği görülmüştür. Adayların bu kategoriyle ilişkili olarak belirttiği "yapıtaşı ve hücre birimi", kavramlarının en fazla 2. sınıflar tarafından, "tanecikli yapı" kavramının en fazla 1. sınıflar tarafından, "parçacık" kavramının ise en fazla 3. sınıflar tarafından ifade edilmiştir. Ayrıca öğretmen adayları tarafından belirtilen "atom modelleri" kategorisiyle ilişkili olan kavramların çeşitliliğinin en fazla 3. sınıfta olduğu ve bu kategoriyle ilişkili olarak çoğunlukla Thomson atom modelinin belirtildiği görülmüştür.

Öğretmen adaylarının kurdukları cümlelerin yarısından azının (\%46.5) bilimsel bilgi kategorisinde yer aldığı ve öğretmen adaylarının genelde benzer cümleler kurdukları görülmüştür. Bilimsel bilgi olarak nitelendirilen cümlelerin kullanım oranının farklılaştığ 1 , 3. sınıfta en az ve 4. sınıfta ise en fazla olduğu görülmüştür. Benzer şekilde kavram çeşitliliğinin en fazla 1. sınıfta olması, üst sınıflara çıkıldığında azalması ve 4. sınıfta bir artış göstermesi bu durumu destekler niteliktedir. Kavram çeşitliliğinin 3. sınıfta azalması öğrenilmiş olan bilgilerin kalıcı olmadığını yani öğrenmelerin yüzeysel olduğunu düşündürmektedir. Diğer taraftan bu durum, öğretmen adaylarının atom kavramını günlük hayatla ne kadar ilişkilendirebildiğinin ve atom kavramına yönelik 
öğretimlerin sorgulanmasının gerekli olduğunu da düşündürmektedir. 1. ve 4. sınıf öğrencilerinin lehine olan bu durum her iki sınıf seviyesinde karşılaşılan ulusal nitelikte sınavların varlığı ile ilişkilendirilebilir.

Adayların kurdukları cümlelerin diğer bir bölümü ise yüzeysel veya günlük hayattan örnekler içeren bilgi kategorisinde yer alırken, önemli bir kısmı bilimsel olmayan veya kavram yanılgısı içeren bilgi kategorisinde değerlendirilmiştir. Bilimsel olmayan veya kavram yanılgısı içeren bilgi kategorisinde yer alan ve öğretmen adayları tarafından sıklıkla tekrarlanan ifadenin "atom maddenin en küçük yapıtaşı/birimidir" olduğu görülmüștür. Diğer taraftan yalnızca 2. sınıfların atomu "hücre birimi" ve "gözle görülebilen" kavramları ile ilişkilendirerek atom ve hücre benzetmeleri yaptıkları görülmüştür.

Çalışmadan elde edilen sonuçlar bütüncül olarak değerlendirildiğinde öğretmen adaylarının gelecekte öğretecekleri kavramlar arasında önemli bir yeri olan atom kavramına ilişkin açıklayıcı ve bilimsel anlamda kabul edilir şekilde algılarını yapılandırmada önemli eksikliklerinin ve güçlüklerinin olduğu görülmektedir. Bu durum, ortaokul 6. sinıf seviyesinden üniversite son sinıf seviyesine kadar farklı seviyelerde ele alınan disiplinler arası doğaya sahip olan atom kavramının öğretim durumlarının niteliklerini tartışmaya açmaktadır. Buna ek olarak, atomun farklı disiplinlerde ve farklı seviyelerde nasıl ele alındığı, hangi öğretim durumlarının kullanıldığı ve bunların kendi içlerinde tutarlı ve birbirini tamamlar nitelikte olup olmadığı analiz edilerek geliştirilmesi önerilmektedir. Farklı branşlardaki öğretmen adaylarının atom kavramına ilişkin algılamalarının belirlenip geliştirilmesine dönük öğrenme ortamlarının tasarlanarak uygulanmasına odaklanan araştırmaların yapılması, alana katkı sağlayacaktır. 